\title{
Front Matter: Volume 9982
}

, "Front Matter: Volume 9982," Proc. SPIE 9982, Unconventional Imaging and Wavefront Sensing XII, 998201 (8 December 2016); doi: 10.1117/12.2260744

EDIE Event: SPIE Optical Engineering + Applications, 2016, San Diego, California, SPIE. United States 


\title{
PROCEEDINGS OF SPIE
}

\section{Unconventional Imaging and Wavefront Sensing XII}

\author{
Jean J. Dolne \\ Thomas J. Karr \\ David C. Dayton \\ Editors
}

31 August-1 September 2016

San Diego, California, United States

Sponsored and Published by

SPIE 
The papers in this volume were part of the technical conference cited on the cover and title page. Papers were selected and subject to review by the editors and conference program committee. Some conference presentations may not be available for publication. Additional papers and presentation recordings may be available online in the SPIE Digital Library at SPIEDigitallibrary.org.

The papers reflect the work and thoughts of the authors and are published herein as submitted. The publisher is not responsible for the validity of the information or for any outcomes resulting from reliance thereon.

Please use the following format to cite material from these proceedings:

Author(s), "Title of Paper," in Unconventional Imaging and Wavefront Sensing XII, edited by Jean J. Dolne, Thomas J. Karr, David C. Dayton, Proceedings of SPIE Vol. 9982 (SPIE, Bellingham, WA, 2016) Six-Digit Article CID Number.

ISSN: 0277-786X

ISSN: 1996-756X (electronic)

ISBN: 9781510603554

ISBN: 9781510603561 (electronic)

Published by

SPIE

P.O. Box 10, Bellingham, Washington 98227-0010 USA

Telephone +1 3606763290 (Pacific Time) · Fax +1 3606471445

SPIE.org

Copyright @ 2016 , Society of Photo-Optical Instrumentation Engineers.

Copying of material in this book for internal or personal use, or for the internal or personal use of specific clients, beyond the fair use provisions granted by the U.S. Copyright Law is authorized by SPIE subject to payment of copying fees. The Transactional Reporting Service base fee for this volume is $\$ 18.00$ per article (or portion thereof), which should be paid directly to the Copyright Clearance Center (CCC), 222 Rosewood Drive, Danvers, MA 01923 . Payment may also be made electronically through CCC Online at copyright.com. Other copying for republication, resale, advertising or promotion, or any form of systematic or multiple reproduction of any material in this book is prohibited except with permission in writing from the publisher. The CCC fee code is 0277-786X/16/\$18.00.

Printed in the United States of America.

Publication of record for individual papers is online in the SPIE Digital Library.

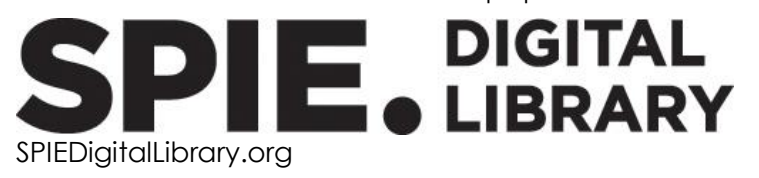

Paper Numbering: Proceedings of SPIE follow an e-First publication model, with papers published first online and then in print. Papers are published as they are submitted and meet publication criteria. A unique citation identifier (CID) number is assigned to each article at the time of the first publication. Utilization of CIDs allows articles to be fully citable as soon as they are published online, and connects the same identifier to all online, print, and electronic versions of the publication. SPIE uses a six-digit CID article numbering system in which:

- The first four digits correspond to the SPIE volume number.

- The last two digits indicate publication order within the volume using a Base 36 numbering system employing both numerals and letters. These two-number sets start with 00, 01, 02, 03, 04, 05, 06, 07, 08, 09, OA, OB ... 0Z, followed by 10-1Z, 20-2Z, etc.

The CID Number appears on each page of the manuscript. The complete citation is used on the first page, and an abbreviated version on subsequent pages. 


\title{
Contents
}

\author{
$\checkmark$ Authors \\ vii Conference Committee
}

\section{SESSION 1 WAVEFRONT SENSING}

998202 Wavefront measurement of vortex beam using ptychographic phase retrieval [9982-2]

998203 Wavefront reconstruction based on quadrant binary phase plate with single far field [9982-3]

998204 Design of wide-field imaging shack Hartmann testbed [9982-4]

998205 Wavefront sensing for anisotropic turbulence using digital holography [9982-5]

998206 Wavefront phase retrieval with multi-aperture Zernike filter for atmospheric sensing and adaptive optics applications [9982-22]

\section{SESSION 2 IMAGE PROCESSING AND WAVEFRONT CORRECTION}

998208 Digital holography wavefront sensing in the pupil-plane recording geometry for distributed-volume atmospheric aberrations [9982-6]

998209 Comparison of polychromatic wave-optics models [9982-7]

9982 OA Predictive dynamic digital holography [9982-8]

9982 OC Shadow imaging of geosynchronous satellites: simulation, image reconstruction, and shadow prediction [9982-10]

9982 OD Numerical techniques for analysis of joint impact of atmospheric turbulence and aerosol scattering effects on imaging systems [9982-12]

\section{SESSION $3 \quad$ ACTIVE IMAGING}

9982 OE Waveguide generated mitigation of speckle and scintillation on an actively illuminated target [9982-13]

9982 OF Inverse synthetic aperture LADAR image construction: an inverse model-based approach [9982-14]

9982 OG Optimal speckle noise reduction filter for air-to-ground range gated laser illuminated imaging [9982-15] 
$9982 \mathrm{OH} \quad$ Adaptive compensation of a direct liquid-cooled solid-state MOPA system [9982-16]

9982 ol Image reconstruction for coherent imaging for space surveillance and directed energy applications [9982-17]

9982 0J Speckle imaging from an array [9982-18]

\section{SESSION 4 SPACE OBJECT DETECTION AND ADVANCED PROCESSING}

9982 OK Improved space object detection via scintillated short exposure image data [9982-19]

$9982 \mathrm{OL}$ Improving space object detection using a Fourier likelihood ratio detection algorithm [9982-20]

\section{SESSION 5 PERFORMANCE CHARACTERIZATION}

9982 ON POAM in starlight: seven years of SAM measurements [9982-23]

998200 The RACHL Experiment: an overview [9982-24]

9982 OP Estimation of Kolmogarity through isotropy [9982-25]

POSTER SESSION

9982 OU Space object detection using Poisson distributed vector projections [9982-29]

9982 OW Wavefront analysis from backscattering phase in rough surfaces [9982-31]

9982 0X Space object detection: receiver operating characteristics for Poisson and normally distributed data [9982-32]

9982 OY Statistically Applied Non-Uniformity Correction (SANUC) [9982-33]

$99820 Z$ Analysis of the multi-hypothesis test for determining pointing angles for telescopes [9982-34] 


\title{
Authors
}

Numbers in the index correspond to the last two digits of the six-digit citation identifier (CID) article numbering system used in Proceedings of SPIE. The first four digits reflect the volume number. Base 36 numbering is employed for the last two digits and indicates the order of articles within the volume. Numbers start with 00, 01, 02, 03, 04, 05, 06, 07, 08, 09, 0A, 0B...0Z, followed by 10-1Z, 20-2Z, etc.

\author{
Alley, Thomas, 05 \\ Anderson, Brian M., 09 \\ Banet, Matthias T., 08 \\ Becker, David J., OL \\ Bordbar, Behzad, 06 \\ Bouman, Charles A., OF \\ Bronson, Ryan S., 04 \\ Cain, Asher N., OU \\ Cain, Stephen S., OK, OL, OY \\ Castro-Ramos, J., OW \\ Chen, Shanqiu, $\mathrm{OH}$ \\ Chen, Xiaojun, $\mathrm{OH}$ \\ Cunningham, Stephanie, OD \\ Dayton, David, OG \\ Diaz-Gonzalez, G., OW \\ Dong, Lizhi, 03, $\mathrm{OH}$ \\ Douglas, Dennis M., OC \\ Dudorov, Vadim V., OD \\ Farwell, Nathan H., 06 \\ Fiorino, Steven T., 09 \\ Gatt, Philip, 05 \\ Gibson, Steve, OA \\ Gonglewski, John, OG \\ Gudimetla, V.S. Rao, Ol \\ Hart, Michael, 04 \\ Hassall, Arthur, OG \\ $\mathrm{He}$, Xing, $\mathrm{OH}$ \\ Holmes, Richard, 0 \\ $\mathrm{Hu}, \mathrm{Ke}, \mathrm{OH}$ \\ Hunt, Bobby R., OC \\ Hyde, Milo W., IV, 09 \\ Kelly, Patrick R., ON \\ Kirk, Jordan T., OZ \\ Lachinova, Svetlana L., OD \\ Lai, Boheng, $\mathrm{OH}$ \\ Lasche, James, OG \\ Liu, Lei, $\mathrm{OH}$ \\ Liu, Wenjin, $\mathrm{OH}$ \\ Liu, Yang, $\mathrm{OH}$ \\ Marker, Dan K., 08 \\ McMurry, Richard, ox \\ Mimura, Hidekazu, 02 \\ Moore, Trevor D., OE \\ Muñoz-Lopez, J., OW \\ Oesch, Denis W., ON, 0O, OP \\ Pellizzari, Casey J., OF \\ Raynor, Robert A., 08, OE \\ Riker, Jim F, OJ \\ Saito, Takahiro, 02
}

\author{
Sanchez, Darryl J., ON, OO, OP \\ Sanchez, Lucas R. W., 04 \\ Santiago-Alvarado, A., OW \\ Schatz, Lauren H., 04 \\ Schmidt, Jason D., OE \\ Scott, R. Phillip, 04 \\ Sheppard, David G., OC \\ Spencer, Mark F., 08, 09, 0A, OE \\ Steinbock, Michael J., 09 \\ Sulaiman, Sennan, $\mathrm{OA}$ \\ Takeo, Yoko, 02 \\ Thurman, Samuel T., 05 \\ Tyler, Glenn A., 0J \\ Van Zandt, Noah R., 09 \\ Vaughn, Jeff L., OJ \\ Vorontsov, Mikhail A., 06, OD \\ Wang, Gang, $\mathrm{OH}$ \\ Wang, Shuai, $03, \mathrm{OH}$ \\ Wang, Zhe, $\mathrm{OH}$ \\ $\mathrm{XU}$, Bing, $03, \mathrm{OH}$ \\ Yang, Ping, $03, \mathrm{OH}$ \\ Yielding, Nicholas J., OY
}


Proc. of SPIE Vol. $9982998201-6$

Downloaded From: https://www.spiedigitallibrary.org/conference-proceedings-of-spie on 26 Apr 2023 Terms of Use: https://www.spiedigitallibrary.org/terms-of-use 


\section{Conference Committee}

Program Track Chairs

Stephen M. Hammel, Space and Naval Warfare Systems Command (United States)

Alexander M. J. van Eijk, TNO Defence, Security and Safety

(Netherlands)

Conference Chairs

Jean J. Dolne, The Boeing Company (United States)

Thomas J. Karr, Defense Advanced Research Projects Agency (United States)

David C. Dayton, Applied Technology Associates (United States)

Conference Program Committee

Stephen C. Cain, Air Force Institute of Technology (United States) James Fienup, University of Rochester (United States)

Wes D. Freiwald, Pacific Defense Solutions, LLC (United States)

Richard B. Holmes, Boeing LTS Inc. (United States)

Liren Liu, Shanghai Institute of Optics and Fine Mechanics (China)

Zhaowei Liu, University of California, San Diego (United States)

Sergio R. Restaino, U.S. Naval Research Laboratory (United States)

Michael C. Roggemann, Michigan Technological University

(United States)

Mark F. Spencer, Air Force Research Laboratory (United States)

Robert K. Tyson, The University of North Carolina at Charlotte (United States)

David G. Voelz, New Mexico State University (United States)

\section{Session Chairs}

1 Wavefront Sensing

David C. Dayton, Applied Technology Associates (United States)

2 Image Processing and Wavefront Correction

Jean J. Dolne, The Boeing Company (United States)

3 Active Imaging

Thomas J. Karr, Defense Advanced Research Projects Agency

(United States) 
$4 \quad$ Space Object Detection and Advanced Processing

Victor L. Gamiz, Air Force Research Laboratory (United States)

5 Performance Characterization

Richard B. Holmes, Boeing LTS Inc. (United States) 